\title{
Canine mammary tumors as a model for human disease (Review)
}

\author{
SOMAIA M. ABDELMEGEED and SULMA MOHAMMED \\ Department of Comparative Pathobiology, Purdue University Center for Cancer Research, \\ Purdue University, West Lafayette, IN 47907, USA
}

Received September 11, 2017; Accepted February 12, 2018

DOI: $10.3892 / \mathrm{ol} .2018 .8411$

\begin{abstract}
Animal models for examining human breast cancer (HBC) carcinogenesis have been extensively studied and proposed. With the recent advent of immunotherapy, significant attention has been focused on the dog as a model for human cancer. Dogs develop mammary tumors and other cancer types spontaneously with an intact immune system, which exhibit a number of clinical and molecular similarities to HBC. In addition to the spontaneous tumor presentation, the clinical similarities between human and canine mammary tumors (CMT) include the age at onset, hormonal etiology and course of the diseases. Furthermore, factors that affect the disease outcome, including tumor size, stage and lymph node invasion, are similar in HBC and CMT. Similarly, the molecular characteristics of steroid receptor, epidermal growth factor, proliferation marker, metalloproteinase and cyclooxygenase expression, and the mutation of the p53 tumor suppressor gene in CMT, mimic HBC. Furthermore, ductal carcinomas in situ in human and canine mammary glands are particularly similar in their pathological, molecular and visual characteristics. These CMT characteristics and their similarities to HBC indicate that the dog could be an excellent model for the study of human disease. These similarities are discussed in detail in the present review, and are compared with the in vitro and other in vivo animal models available.
\end{abstract}

\section{Contents}

1. Introduction

2. Cell lines as a model for HBC

3. Animal models of HBC

4. Conclusion and future perspectives

Correspondence to: Professor Sulma Mohammed, Department of Comparative Pathobiology, Purdue University Center for Cancer Research, Purdue University, 625 Harrison Street, West Lafayette, IN 47907, USA

E-mail:mohammes@purdue.edu

Key words: cell lines, rodent, rat, mice, cat, dog, xenografts, model, canine, mammary tumors, breast cancer

\section{Introduction}

Breast cancer is the most commonly diagnosed cancer and the leading cause of cancer-associated mortality among women worldwide (1). In 2012, 2 million females globally were diagnosed with breast cancer (2). In the USA, the American Cancer Society estimates diagnoses of approximately 2,350 new men cases and around 231,000 new cases of invasive breast cancer among women in 2015 (3). As a result, breast cancer prevention and therapeutic intervention are significant objectives for a number of researchers. These measures require an understanding of the biology of the disease during its development and progression. To gain this knowledge, basic clinical research is necessary. Due to the scarcity of human tissue samples and the ethical issues regarding conducting such research in humans, researchers require in vivo and in vitro human breast cancer (HBC) models (1). The most commonly used in vitro model are cell lines; additionally, an organotypic culture model has been recently developed. While cell lines are the most widely used model for pre-clinical research, they have limitations, which make them poorly representative of real cancers (4). In vivo models include xenografts, as well as syngeneic and genetically engineered mice, cats and dogs (5). Rodent models are considered the most useful model of breast cancer, but they also have limitations (5). This review will show how dogs, according to several aspects and studies is considered the optimal model for human breast cancer.

\section{Cell lines as a model for HBC}

Established breast cancer cell lines are used as in vitro models in the majority of breast cancer research laboratories. There are a number of advantages to their use, including: Cell homogeneity, low cost, uncomplicated handling, and straightforward removal from frozen stocks. In addition, cell lines replicate indefinitely. Several breast cancer cell lines are hormone-dependent, which allows for the analysis of estrogen and progesterone-regulated signaling pathways in breast cancer. MCF-7 is considered to be an ideal model for hormone response studies due to its particular hormone sensitivity as a result of the expression of estrogen receptors (ER) (6). In addition, the effects of the chemical inhibition of signaling pathways and altered gene function on the tumorigenicity of the cells may be examined by transplanting them as xenografts into appropriate, immunocompromised animals. However, breast cancer cell line usage has a number of disadvantages, which include: A propensity for genotypic drift; 
and phenotypic selection due to the continuous culturing of rapidly growing, specific clones from the subpopulations $(7,8)$.

Furthermore, the culturing of breast cancer cells from primary tumors via the extraction of viable tumor cells from the surrounding stroma is challenging $(4,9)$; however, five cell lines were recently isolated from a ductal carcinoma in situ (DCIS) excision from a Singaporean patient of Chinese origin (10), which represents a rich resource for cell physiology and drug discovery studies for early stage breast cancer. In comparison to primary tumors, metastatic tumors provide large numbers of viable, detached tumor cells with little or no contamination from tumor stroma cells, particularly metastatic effusions (11). Long-term culturing success is low, even from samples isolated from metastatic tumors $(4,11,12)$. The majority of available breast cancer cell lines were isolated from pleural effusions (12). Other cells have been obtained from less typical origins, including: MDA-MB-361, which originated from a brain metastasis $(12,13)$; HH375 and HH315, which originated from supraclavicular and abdominal lymph node metastases, respectively (14); LCC15-MB, which was obtained from a femoral metastasis (15); MALL, which originated from bone marrow aspirate (16); and MAST and ZR-75-1 cells, which were extracted from ascitic fluid $(17,18)$. Furthermore, it has been demonstrated that certain breast cancer cell lines have a tropism for certain metastatic sites (19). MA-11 cells frequently metastasize to the brain, whereas MT-1 cells frequently metastasize to the bone and bone marrow in mice (19).

Cell lines are considered to be relatively unrepresentative models of the tumors from which they were obtained, despite their essential role in the majority of aspects of cancer biology research (20). The majority of breast cancer lines have a metastatic origin and their association with primary tumors is an important issue (8). In addition, the pure and clonal population of any breast cancer cell line is expected to inadequately reflect the presumed heterogeneity of breast tumors, regardless of its metastatic or primary origin $(8,21)$. This heterogeneity reflects the tumor progression through pathological and clinical phases, starting as an atypical hyperplasia, followed by carcinoma in situ, invasive carcinoma, and metastatic disease (22). These stages are mediated by the various genetic and phenotypic changes in an individual cell, followed by clonal selection and expansion, which leads to intratumoral diversity (22). The culture conditions of the cells may eliminate a number of types of cancer cells that were originally present in the tumor samples. For example, certain cell lines are unable to grow well on plastic and require specific tumor environments for specific factors (23). These cells are unlikely to be included in the panel of currently available breast cancer cell lines. Furthermore, cancer cells are genetically unstable, and may undergo specific genotypic and phenotypic alterations as a result of long-term culturing and storage. Over 20 years ago, a cross-contamination of breast cancer cell lines with HeLa cells was identified, which had produced false cell lines (8). Accordingly, it is imperative that cell lines are well characterized prior to research use (8). Whether or not the few frequently used breast cancer cell lines precisely reflect intertumoral heterogeneity has been extensively debated (20).

Studies recently established and characterized unique, novel breast cancer cell lines, including from primary lesions (24-26). The process of selecting cells to fit the criteria of a bona fide continuous cell line is intensive. The criteria include: A tendency toward anchorage-independent growth; altered cytomorphology; increased growth; increased clonogenicity; reduced serum dependency; changes in ploidy; tumorigenicity in nude mice; and an unlimited lifespan (27). Established cell lines will be continued to be used as models for breast cancer due to their distinct advantages. However, it is necessary that researchers are aware of the limitations of cell lines, and the possible effects on experiments and results. Cell lines isolated from primary breast tumors are now available through conventional cell line repositories and are worth consideration as research tools (8).

\section{Animal models of HBC}

Rodent models. Mice and rats are the most important models for HBC, and has enabled scientists to understand the fundamental events that cause breast cancer initiation, development and progression (28). In addition, mouse models offer a number of opportunities for studying breast cancer treatment and prevention (29).

Inbred mice. Inbred mice were first used as a unique model for studying susceptibility to specific cancer types, including breast cancer, in 1920 (30). The use of inbred strains demonstrated that certain hormonal, environmental and genetic factors, including mouse mammary tumor virus (MMTV), have important roles in determining the susceptibility to breast cancer (30). Inbred mice have a carbon-copy genetic background, so they are expected to generate analogous responses to similar treatments and exposures (31). Gathering data from standardized collections around the world allows cancer researchers to investigate virtually any phenotype of interest, and utilize the depth and breadth of knowledge on that model system.

Transgenic and genetically engineered mice models (GEMMs). In 1980, GEMMs were developed through the removal of specific tumor suppressor genes or the overexpression of specific oncogenes, in a germline-specific manner (32). These models have been used to assess signal transduction pathways, pathobiology and gene expression signatures. They have also been used to evaluate the efficacy of chemoprevention strategies (33). Using GEMMs, researchers have the ability to examine the effect of single or multiple genes on the evolution of tumors in the breast. GEMMs have conditional alleles that induce the mutations necessary for specific cancer types (34). In a number of cases, GEMMs more faithfully, compared with other animal models, represent the full biochemical, proteomic, genetic, phenotypic and histological characteristic features of specific human tumors (35). In 2007, a novel approach using the avian leucosis virus receptor $\mathrm{A}$ as a transgene targeted to the mammary gland was published (36). These models are advantageous as they mimic the condition of initiated cells within a field of normal cells. Furthermore, if a means to modify the vector to infect particular subpopulations is developed, the phenotypes arising from certain cell subtypes can be traced more accurately (36).

Carcinogen-induced mice models. Several rodent studies have demonstrated that exposure to cancer-causing agents, including 
radiation or chemicals produces specific tumors, have effects of these agents resulting in uncontrolled cell growth due to mutations and alterations $(37,38)$. These models recapitulate the multi-stage and time-dependent development of tumor pathogenesis in the reaction to tumor-promoting agents and etiologically relevant environmental carcinogens (39). Researchers generated these models in outbred rodent breeds of various genetic backgrounds, and reported a high frequency of organ-specific cancer types with highly reproducible phenotypes. Furthermore, these models have histopathological, biochemical and molecular features that resemble the developmental consequences of specific human tumors, which make them clinically and biologically important $(39,40)$.

As with traditional xenograft models developed in syngeneic hosts and GEMMs, carcinogen-induced tumor models allow the assessment and modulation of the function of humoral and cellular immune components in tumor immune surveillance and evasion mechanisms. The participating role of chronic and acute inflammatory processes in cancer development and progress is clearly represented in this model $(41,42)$. The carcinogen-induced tumor model is particularly relevant given the epidemiological and experimental association between human tumor development and chronic inflammation (43). In addition, these models have been used in chemoprevention studies to assess the therapeutic effects on tumor development and growth $(29,44)$. A number of experimental agents were determined to be useful in the management or prevention of certain human tumors in their analogous organ-specific, carcinogen-induced cancer models (45-48).

The molecular, phenotypic and histological similarities, the general predilection for metastasis, and the utility in inflammatory and immune response studies make these models beneficial translational biology systems for drug discovery and early non-clinical drug development stages.

Xenograft mice models. Currently, mice are used in xenograft experiments, in particular severe combined immunodeficiency mice and nude mice. These two strains naturally induce single gene mutations that compromise the immune system. HBC cell lines are relatively easily transplanted into these animal models. For invasive breast cancer, the reported success is $7-20 \%$ (49). This range depends on a number of factors, including the implantation site, strain, hormonal supplementation and the age of the mice. However, pre-invasive breast cancer samples, including DCIS, were reported to be more successful in developing xenografts $(50,51)$.

Rats as a model. The rat is considered to be the first domesticated laboratory mammal used as a model for HBC research, used as early as 1912. Rats are easier to use in research than mice, as they are larger in size $(52,53)$. A number of comparative studies have illustrated the histological similarities between $\mathrm{HBC}$ and rat mammary tumors $(50,51)$. The incidence of breast cancer in rat models is either spontaneous, or generated by the transgenesis of activated oncogenes or the induction of mutations in tumor suppressor genes (54). Chemical carcinogens have been used to induce breast cancer in the rat mammary gland for $>50$ years, most commonly N-nitroso-N-methylurea or 7,12-dimethylbenz(a)anthracene (55-57). These chemically-induced tumor models have been frequently utilized in the investigation of hormone-dependent breast tumors, and the role of pregnancy in preventing breast tumors (58-60). It was identified that chemically-induced tumors in rats are hormone-dependent adenocarcinomas, in contrast to the majority of mammary tumors that arise in GEMMs (51).

Limitations of rodents as models for breast cancer. Although rodents are the most frequently used animal models in cancer research, there are a number of limitations to their role. Firstly, there are significant differences between the biology of rodents and their tumors, and that of humans and their tumors. There are immanent differences in the developmental programs of rodents and humans. Size is a notable difference, which affects the number, differentiation and maturation of transformed cells (61). In addition, observable tumors in mice require rapid growth progression relatively, as the lifespan of rodents is relatively short compared with that of humans. Mice can develop severe malignant lesions with multiple genetic alterations within 6-18 months (61). Furthermore, rodent cells are much easier, compared with human cells, to transform with chemical carcinogens or oncogene transfection in vitro, possibly due to their relatively poor control of genetic stability, less effective DNA repair, or altered regulation of gene expression (62).

Another notable difference is in the tumor pathology and biology observed between rodents and humans. Fewer genetic changes are required for rodent cell transformation in vitro, and potentially also in vivo (37). For example, $~ 50 \%$ of $\mathrm{HBCs}$ are hormone-dependent at diagnosis, whereas the majority of mouse tumors are hormone-independent, with notably low ER and progesterone receptor (PR) levels (61).

Although rodents are intrinsically more susceptible than humans to carcinogenesis, in wild-type rodents, sporadic cancers are relatively rare (1). In the past, mouse breeds prone to mammary tumors were produced by vertical transmission through milk or Bittner factor, which was later demonstrated to be due to MMTV $(63,64)$. By contrast, viruses are not convincingly involved in $\mathrm{HBC}$ oncogenesis, except as probable cofactors (64). Furthermore, rodent cells are easily immortalized $(65,66)$. Primary human cells and mouse cells also exhibit considerable differences in telomerase regulation and telomere dynamics. Telomeres are considerably longer in laboratory mice (40-60 kb) compared with that of humans $(10 \mathrm{~kb})$, and telomerase is highly expressed in the tissues of adult mice (67). Cancer cells in humans avoid replicative senescence by maintaining telomeres through telomerase reactivation and other mechanisms, which may not be analogous to tumor development in mice (67).

Although the morphological patterns of lesions in humans and rodents initially appear to be similar, the detailed features of the majority of mouse tumors are not similar to HBCs, and cannot be classified as the same pathological grades and types $(68,69)$. Another major difference is that small animals, including rats and mice, consume higher oxygen levels on a per-cell basis, compared with large animals (70). This results in distinct cellular microenvironments, particularly in comparatively hypoxic and avascular tumors, in which hypoxia-induced genes may influence differentiation and growth to an extent that may be unrepresentative of these processes in human tumor development (71).

Despite the usefulness of GEMMs in breast cancer research, it is difficult to regulate the extent of GEMM gene expression 
due to multiple copies of one gene, which may be inserted into the genome (72). Another limitation of these models is that the removal of tumor suppressor genes, if not initially intended to the mammary gland, may have lethal effects on the neonate or fetus (29). GEMMs also exhibit fundamental differences at the organism and cell levels. GEMMs usually reproduce highly specific tumor formations, follow all lesion progression aspects and primarily their design depends on the awareness of tumor genetics of human $(62,72)$. During the use of transgenic mice, the type and degree of genetic abnormalities, which create disease, must be determined in association with those that create the disease in humans, in order to evaluate if they disagree and therefore meaning that they are unsatisfactory models (62). Asynchronous tumor development in the transgenic host is considered a major disadvantage of GEMMs (73). These models are frequently characterized by low penetrance, miscellaneous tumor frequency, and latent growth properties and tumor development $(69,71)$. Another challenging problem in establishing GEMMs of certain cancer types is the scarcity of tissue-specific promoters, which manage transgene expression in the adult cells of the targeted tissue (74). Furthermore, GEMMs incur significant cost, time and effort for the development and maintenance required to produce analytically meaningful data (32). In addition, as in the majority of rodents, the metastatic patterns vary from human cases (32). In humans, breast cancer usually spreads via the lymphatic system, beginning in local lymph nodes, and spreading to the bone, liver, brain and the lung (75). Whilst in rodents, mammary tumors metastasize particularly to the lung via the blood (76).

In spite of the important role of carcinogen-induced models, they still have basic restraints for regular usage in the early stages of drug discovery (77). Even though these models require minimal initial cost for implementation, they require significant time and high cost for maintenance (77).

While the rat model serves an important role in breast cancer research, there are a number of disadvantages to its use. One limitation is that rat mammary tumors rarely metastasize (51). Compared with mice, the limited availability of rat genetic engineering strategies-specifically nuclear transfer for gene knockouts-has reduced the extensive use of rats as genetic models for the disease (78). A mutagenesis strategy for effectively generating breast cancer-associated (BRCA) 1 and BRCA2 gene mutants was developed (79); however, this method still requires more efficient technologies for the complete gene knockouts used in breast cancer investigation.

Cats as a model. A previous study focused on feline mammary tumors to identify the similarities between feline and human disease (80). Studies examining the similarities between human premalignant lesions and feline mammary intraepithelial lesions (IELs) observed that the latter are characterized by a spontaneous onset and high prevalence, similar to humans, as well as all the morphological features of human pre-invasive breast tumors (81). These lesions were also distinguished by the loss of PR and ER expression, promoting the cat as a model for pre-invasive ER- and PR-negative breast tumors (82). Weijer et al (83) reported that, as in humans, feline tumor lesion size, method of growth and histological grade are associated with disease prognosis. Additionally, it was indicated that feline mammary carcinomas are able to provide a suitable model for comparative studies to examine therapeutic interventions, and serve as an intermediate model for the study of mammary tumor histogenesis and etiology (83-86).

Limitation of cats as a model for breast cancer. Despite the similarities determined between human and feline disease that make the cat as a good model for HBC studies, there is significant time used to gather the minimum number of cats required for a single study within a limited time period (80). Another factor that may prevent the results of a study from being homogeneous, is that the study is reliant on pet owners when applying postoperative treatment in cases that are not in hospitals and following up the study (81). Additionally, the high cost required for studies on cats is considered a large disadvantage (85).

Dogs as a model. In recent decades, clinical and molecular similarities have been identified between HBC and canine mammary tumors (CMT) (87). The clinical similarities include the spontaneous tumor incidence, onset age, hormonal etiology and the identical course of the disease. Furthermore, the factors that affect the clinical outcome, including the tumor size, clinical stage and lymph node invasion, are identical (88). Fig. 1 depicts the histopathological similarities of mammary intraepithelial lesions between canine mammary tumor and human breast cancer. The molecular characteristics, including steroid receptor, epidermal growth factor (EGF), proliferation markers, metalloproteinase and cyclooxygenase overexpression, and p53 mutation, also mimic HBC (88). Table I demonstrated the similarities between canine mammary tumor and human breast cancer.

The reported incidence of HBC and CMT has increased recently (89-91), due to the frequent widespread usage of mammography screening, and the increased awareness of dog owners (88). The higher incidence of CMT provides an increased sample size for clinical trials in comparative medicine.

As in human females, the most common spontaneous malignancy in female dogs is mammary neoplasia (92), and premalignant lesions are prevalent in canine mammary glands (93). In females, breast cancer development is affected by estrogen; similarly, non-spayed female dogs $<2$ years old have a 4-fold higher risk of tumor occurrence compared with spayed dogs of the same age (94-96).

\section{Morphological and histological features of canine mammary cancer.}

i) Molecular biology. During puberty, steroid hormones are essential for mammogenesis (97); during pregnancy, the complete development of lobules and alveoli is induced by the stimulation of progesterone and estrogen (97). In CMT and HBC,ER expression is associated with the pathological features of the disease and the degree of tumor differentiation (98).

In CMT, it was identified that larger tumors with skin ulcerations and reduced prognosis exhibit a reduced level of ER $\alpha$ expression (99). In humans, ER $\beta$ has a greater associated with benign tumors, and its higher expression in a tumor of a lower malignancy grade is an indicator of a relatively good prognosis (99). The expression of ER $\beta$ in HBC has been associated with an extended survival time in patients with ER $\alpha$-negative tumors treated with tamoxifen (100). Divergences in ER expression have a significant effect on endocrine therapy; 
Table I. Similarities between canine mammary tumor and human breast cancer.

\begin{tabular}{|c|c|c|}
\hline Similarity features & Humans & Dogs \\
\hline Occurrence & Spontaneous & Spontaneous \\
\hline Onset age & Median age, 62 years & $\begin{array}{l}\text { Median age, } \sim 10.5 \text { years ( } 10.5 \text {-year-old dog, } \\
\text { equivalent to a } 65.5 \text { year old woman) }\end{array}$ \\
\hline Course of the disease & Identical in human and dog & Identical in human and dog \\
\hline Size of the tumor & Similar in human and dog & Similar in human and dog \\
\hline Clinical stages & Identical in both species & Identical in both species \\
\hline Invasion to lymph nodes & Identical in human and dog & Identical in human and dog \\
\hline $\begin{array}{l}\text { Most common spontaneous } \\
\text { malignancy }\end{array}$ & Mammary neoplasia & Mammary neoplasia \\
\hline Estrogen dependency & $\begin{array}{l}\text { Long exposure to estrogen increases } \\
\text { the risk of tumor occurrence }\end{array}$ & $\begin{array}{l}\text { Non-spayed dogs have a fourfold higher } \\
\text { danger of tumor occurrence than spayed dogs } \\
<2 \text { years old }\end{array}$ \\
\hline Most common histological type & Invasive ductal carcinoma & Carcinomas \\
\hline Premalignant lesions & Prevalent & Prevalent \\
\hline Molecular markers & $\begin{array}{l}\text { A number of genes were identified to } \\
\text { perform a critical role in carcinogenesis } \\
\text { of mammary tumors }\end{array}$ & $\begin{array}{l}\text { It was determined that these genes have } \\
\text { identical role in carcinogenesis of canine } \\
\text { mammary tumors }\end{array}$ \\
\hline Mammographic abnormalities & $\begin{array}{l}\text { Dog and human mammary neoplasm } \\
\text { have similar microcalcifications and } \\
\text { macrocalcifications }\end{array}$ & $\begin{array}{l}\text { Dog and human mammary neoplasm have } \\
\text { similar microcalcifications and } \\
\text { macrocalcifications }\end{array}$ \\
\hline
\end{tabular}

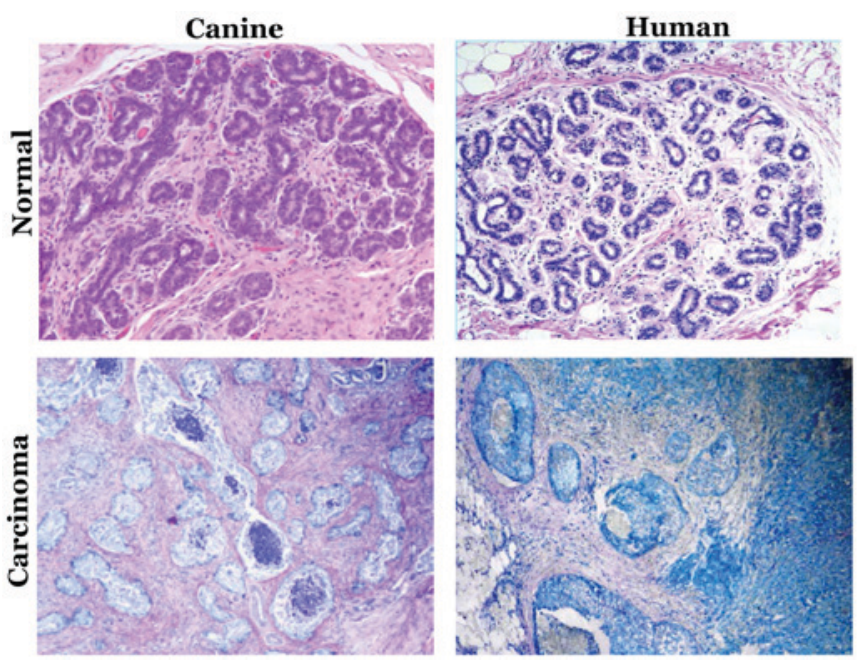

Figure 1. Mammary intraepithelial lesions in canine and human mammary biopsies. Hematoxylin and eosin-stained mammary biopsies of normal (upper part), and carcinoma gland (lower part). Magnification, x200. Modified with permission from Antuofermo et al (93).

therefore, selective ER modulators that act as full agonists for $\mathrm{ER} \beta$ and antagonists for ER $\alpha$ may be effective in CMT treatment, particularly as a chemoprevention strategy (101).

PR expression has been demonstrated as an important indicator of breast cancer recurrence in humans (102). A negative PR status is associated with a reduced prognosis $(101,103)$. A combination of PR and ER expression status has also been associated with overall survival. ER $/ \mathrm{PR}^{-}$cases are associated with the worst survival rates, followed by $\mathrm{ER}^{-} / \mathrm{PR}^{+}, \mathrm{ER}^{+} / \mathrm{PR}^{-}$ and $\mathrm{ER}^{+} / \mathrm{PR}^{+}(42)$.
In CMT, ER and PR expression are common in normal and benign tissues. It was observed that $\mathrm{ER}^{+} / \mathrm{PR}^{+}$was the most common status of benign tumors, whereas an $\mathrm{ER} \alpha^{-} / \mathrm{PR}^{+}$ status was twice as common as $\mathrm{ER}^{+} / \mathrm{PR}^{+}$in malignant cancer (77). Malignant tumors tend to lose hormonal dependency as the disease progresses towards metastasis, therefore these tumors and their metastases have a tendency to be $\mathrm{ER}^{-} / \mathrm{PR}^{-}(95)$. In $\mathrm{HBC}$, the ER-/PR- status is associated with a poorer prognosis (104).

Insulin-like growth factor-1 (IGF-1) and growth hormone (GH) have been investigated in human breast carcinogenesis $(45,105)$. Previously, it was identified that the inhibition of GH/IGF-1 may prevent pre-neoplastic breast disease and cancer (46). In dogs, progestin stimulates the mammary gland tissue to locally produce GHs (48). It was assumed that the epithelial hyperplasia that was observed following the administration of progestin and the subsequent biosynthesis by the mammary gland was mediated by autocrine GHs $(47,105)$. The full-length canine GH receptor (GHR) sequence in CMT has expanded homology with the GHR sequence of humans and various other species (106). This evidence may support the utility of GH in comparative pathology. According to novel data, an association between $\mathrm{GH}$ and progesterone levels in CMT homogenates has been identified, indicating that the progesterone/GH axis has an evident role in CMT (107). The GH/IGF-1 axis is also significant in CMT prognosis (108). Pre-surgical serum concentrations of the IGF-1 content of the malignant lesions and tissue GH levels are associated with a reduction in the post-surgical survival rate (109). Another study demonstrated that the concentrations of serum IGF-1 in female dogs with malignant tumors were higher compared with in healthy controls (110). The predictive value of IGF-1 
and GH in mammary tumors was established for the first time in veterinary and human medicine (111). This evidence has facilitated novel therapeutic approaches, including the use of pegvisomant as a GH-competitive antagonist $(108,111)$.

Prolactin is characterized by its lactogenic activity, as well as functioning as a growth factor in breast tumors (112). It has been observed in breast cancer that prolactin supplementation promotes the survival of mammary tissue, and that the clinical condition of patients may improve following hypophysectomy, indicating a hormonal dependency on prolactin (112). HBC cells and tumors co-express sex steroid hormone and prolactin receptors, which are cross-regulated (113). This may clarify the collaboration between sex steroid hormones and prolactin during neoplastic growth and mammary development, in particular between prolactin and progesterone (113). It is proposed that prolactin and steroid hormones act as local growth factors, stimulating malignant tumor proliferation (109). In addition, it was determined that clinical tumor features were associated with prolactin levels in tissue homogenates, demonstrating an association with steroid hormone levels (114). Further studies are required to understand the effect of prolactin on prognosis in veterinary medicine.

ii) Molecular markers. In recent decades, a number of molecular markers associated with tumor development have been identified. Of the number of genes identified to be responsible for breast cancer occurrence and development in humans, a number were also demonstrated to serve an essential role in the carcinogenesis of mammary tumors in dogs (115). These markers include BRCA gene mutations, EGF receptor (EGFR), $\mathrm{Ki}-67$, human epidermal growth factor receptor (HER2)/neu, p53, p63, matrix metalloproteinases, phosphatase and tensin homolog, heat-shock proteins, mucins, maspin, Sialyl Lewis $\mathrm{X}$ antigen and cyclooxygenase-2 (88). Uva et al (116) examined the oncogene expression common between human and canine breast cancer, and reported significant similarities in the signaling networks that regulate mammary cancer biology. Germline mutations in BRCA genes have been associated with a relatively high risk (4-fold) of mammary tumor development in certain breeds of dogs $(117,118)$. An association between the expression of mutated BRCA1 or BRCA2, and RAD51 recombinase (RAD51), a DNA-repairing protein that is, when upregulated, associated with the development of mammary tumors, was also reported in dogs (119). Nieto et al (120) revealed that the expression of BRCA1 was reduced in malignant CMT lesions. Reverse transcription-quantitative polymerase chain reaction on laser-microdissected tissue samples of normal mammary gland epithelia, simple canine adenomas and adenocarcinomas free from non-neoplastic epithelial and stromal cells were used to study the differential mRNA expression of RAD51, BRCA1 and BRCA2 (121). In that study, the expression of BRCA1 was not clearly associated with the histological criteria of malignancy, in contrast to human tumors; however, BRCA2 and BRCA1 were overexpressed in $50 \%$ of lymph node metastases, whereas RAD51 was overexpressed in $50 \%$ of primary tumors and $80 \%$ of lymph node metastases. According to these conflicting results, a reduction in expression in more malignant cells may be expected. The conclusion was that this overexpression was induced by the inhibition of proliferation due to a negative regulatory loop in which BRCA2 was produced by cellular proliferation (122).

EGFR, also known as HER1, is considered a molecular marker in triple-negative breast cancer, including $\mathrm{ER}^{-}, \mathrm{PR}^{-}$and HER2/neu (123). In CMT, cases with positive EGFR expression are associated with reduced disease-free and overall survival rates. Additionally, it was reported that benign and hyperplastic lesions consistently express EGFR in the myoepithelial cells of humans and dogs (124). It has been indicated that in tissues with high concentrations of progesterone and EGF, a mechanism involving the angiogenic effects of EGF and the induction of proliferation by progesterone may exist in CMT (125).

HER2/neu is another important prognostic factor (126). HER 2/neu ${ }^{+}$tumor-specific therapy has yielded promising treatment results (126). In the study by Rungsipipat et al (127), out of 79 CMT cases, HER2/neu was expressed in a $19 \%$ adenocarcinomas and $\sim 50 \%$ benign tumors, including simple and complex adenomas. In a study of malignant CMT and HBC, the rate of HER2/neu expression was similar (20 and 30\%) (128). Kerns et al (128) detected the co-expression of HER2/neu and p53 mutation, which induced malignant cell behavior. Similar to humans, four phenotypic subtypes have been identified in malignant CMT, according to the immunohistochemical expression of HER2 and ER: HER2 overexpressing (ER-HER2 ${ }^{+}, 8.3 \%$ ); basal-like (ER-/HER2- 29.2\%); luminal A (ER ${ }^{+} / \mathrm{HER}^{-}$, 44.8\%); and luminal $\mathrm{B}\left(\mathrm{ER}^{+} / \mathrm{HER} 2^{+}, 13.5 \%\right)(129,130)$. Individuals diagnosed with the basal-like subtype have reduced survival rates (131). This indicates the molecular heterogeneity of HBC and CMT, providing further evidence that CMT is a potential model for the study of HBC.

The Ki-67 antigen is a nuclear protein highly expressed in proliferating cells prior to mitosis (132). Ki-67 labeling has been identified in different types of human and canine tumors (133). For humans, immunohistochemical determination of Ki-67 expression in mammary carcinomas has been indicated as a prognostic marker for relapse-free survival time (134). Proliferating cell nuclear antigen (PCNA) and other proliferation markers have been studied in combination with Ki-67 (135). The reliable prognostic value of PCNA in other types of malignancy has been described by several studies (135); however, it was determined to be a poor prognostic indicator for human mammary carcinoma (135). The immunohistochemical expression of $\mathrm{Ki}-67$ and PCNA has also been studied in CMT; the expression of $\mathrm{Ki}-67$ has been associated with a poor prognosis (133). PCNA was observed to be more frequently expressed in malignant CMT than in normal mammary glands, hyperplasia and benign tumors (136). Similar to $\mathrm{HBC}$, the expression of $\mathrm{Ki}-67$ in benign and malignant tumors was reported to be considerably associated with the presence of remote metastases, as well as associated with the histological criteria of malignancy and the PCNA index (137).

Following DNA damage, the p53 tumor suppressor gene has an important role in regulating cell growth. Deregulated cell proliferation occurs following mutations of this gene, which causes tumor formation and progression (138). In HBC, p53 gene mutation leads to the accumulated nuclear expression of the p53 protein. This event has prognostic value, and is usually indicative of a relatively poor survival time (139). In CMT, the expression of mutant $\mathrm{p} 53$ has also been identified as a valuable prognostic marker (140). The frequency of p53 mutation in CMT is 20\%, 
which is analogous to that detected in HBC (141). In humans and dogs, mutations in the conserved domains of p53 appear to have an essential role in the carcinogenesis of mammary glands (142). It was identified that p53 mutations in CMT occur within the second, fourth and fifth exons, and Ala125Val point mutations are common between human and canine p53 genes (143). A study of aggressive CMT carcinomas indicated an association between p53 mutations and the aggressive type (143), which has also been concluded in HBC studies (143). Additionally, as the arrangement of p53 gene products and coding exons are similar in both species, there may be a shared therapeutic target (141).

The p63 gene is from the p53 gene family. p63 is involved in the regeneration of epithelial stem cells and is not considered a tumor suppressor gene (144). It was demonstrated to be overexpressed in the basal epithelial cells of various human cancer types (144). The p63 gene may act as a tumor promoter in specific pathological conditions (145). In humans, p63 is overexpressed in the breast carcinoma basal phenotype, in which it regulates the growth and differentiation of stratified epithelia (146). In humans, p63 is a specific and sensitive indicator for myoepithelial cells (147). Strongly positive p63 staining indicates myoepithelial differentiation in papillary carcinomas (147). p63 has been determined to be a strong myoepithelial cell indicator in dogs, and is important for the differentiation of myoepithelial or basal cells from stromal myofibroblasts (148). Furthermore it was determined that the overexpression of p63 was associated with stem and myoepithelial cells, which may explain the histogenesis of CMT (149).

iii) Mammography and ultrasound imaging. In order to confirm that the dog is a model that represents HBC in every aspect, X-ray mammography has been used to define the similarities between human and dog specimens. X-ray mammography is currently used to detect human DCIS by identifying the presence of microcalcifications (150). Such microcalcifications are identified in $42-72 \%$ of DCIS cases $(150,151)$. The existence of microcalcifications alone is used to diagnose $~ 90 \%$ of nonpalpable DCIS (152). Mammogram data are classified by a Breast Imaging Reporting and Data System (153) (BI-RADS), according to the morphology and distribution of calcifications, into three types: Typical benign, intermediate concern, and higher expectation of malignancy (153). The detection of DCIS has improved due to mammography use; however, whether the detection of DCIS by mammography leads to a decrease in the breast cancer mortality rate has yet to be fully investigated (154). Thus, they assessed the dog as a model for studying pre-invasive and invasive breast tumors. The study identified mammographic abnormalities in canine mammary pre-invasive lesions, benign tumors and malignant tumors that were similar to the abnormalities associated with HBC. These abnormalities include the pattern, presence and distribution of microcalcifications and macrocalcifications (154). BI-RADS categorization was thus considered a precise method for the detection of mammary malignant lesions in canines, with high specificity and sensitivity (155).

In a study of 88 mammary glands excised from 40 female dogs of different breeds, mammographic features, including microcalcifications, macrocalcifications, mass margin and shape, and their association with the histological diagnosis, were identified in 78/88 mammary glands (155). The remaining
10 mammary glands exhibited a normal mammographic appearance (155). Calcification was identified in 42/78 glands (54\%), of which 19 glands (24\%) had macrocalcifications and 23 glands (29\%) contained microcalcifications. Lesions with microcalcifications $(29 \%)$ were amorphous/indistinct $(5 / 23$, $22 \%)$, linear branching $(4 / 23,17 \%)$ or pleomorphic regional and diffuse $(14 / 23,61 \%)$, and the majority were associated with atypical IELs and malignant tumors. On the other hand, 11/19 lesions with macrocalcifications (57\%) were 'popcorn-like', with regional distribution in four glands (24\%) and diffuse distribution in seven glands (36\%). The other 8/19 (42\%) were round, with regional localization. Lesions with macrocalcifications were diagnosed as malignant and benign tumors, primarily of the complex type or IELs without atypia. In addition, mass margins and shape were evaluated by mammography in 54/78 (69\%) glands. Of the benign lesions, 21/26 (81\%) were oval or round masses and 12/26 (46\%) had circumscribed margins. Of the malignant lesions, $12 / 25(48 \%)$ were irregular in shape, and 22/25 (88\%) exhibited indistinct margins. The ultrasound abnormalities of 46/78 mammary lesions corresponded with histological data. Using ultrasound, calcifications were identified in $41 \%$ of the lesions and $53 \%$ were associated with malignant tumors. An oval shape was observed in 25/40 (62.5\%) benign or malignant tumors. Of the benign lesions, $78 \%$ featured a well-circumscribed margin, whereas $80 \%$ of malignant lesions featured irregular margins (155).

The study indicated that dog and human mammary neoplasms form similar microcalcifications and macrocalcifications. It also indicated a similar process of cancer pathogenesis between humans and dogs. Furthermore, it was determined that the sonographic and mammographic features of benign and malignant canine mammary IELs were associated with the histopathological data. The BI-RADS categorization was concluded to be an excellent predictor of malignant canine mammary lesions. In addition, the study indicated that dogs are suitable models for HBC (155).

Limitations of dog as a model for breast cancer. Using pets as a model for studying has the same limitations as in case of cats, including high cost and time consumption, and reliance on the owner of the pet post-treatment (156). These are considered significant limitations for using dogs as a model for HBC.

\section{Conclusion and future perspectives}

CMT resembles human mammary tumors in every aspect. Invasive mammary tumors, as well as pre-invasive lesions, are similar to those in human in histopathological, molecular and imaging characteristics, and clinical outcomes (90). Mammary tumors develop in dogs spontaneously without genetic or chemical manipulation with an intact immune system. Recently, there has been increasing interest in the development of immunotherapy and immunoprevention strategies to treat or prevent cancer (157). Dogs are an excellent resource for testing these modalities in a preclinical setting, as remarkable similarities exist between humans and dogs with regard to tumor infiltrating lymphocytes (TIL), including the association between TIL numbers and mammary tumor aggressiveness, the association between the $\mathrm{CD} 4^{+} / \mathrm{CD}^{+} \mathrm{T}$-cell ratio and survival rate, the promotion of tumor progression by 
Th2 cells, and the association between Treg cell numbers and poor prognostic factors (158).

Furthermore, the development of prophylactic vaccines for cancer faces multiple challenges, including the low cancer incidence in humans, the years it takes for the efficacy of the vaccine to be determined and the cost of human clinical trials. The dog model addresses these challenges, as the published work has demonstrated that CMTs are so prevalent in non-spayed female dogs, that $50 \%$ of randomly screened dogs $(n=150)$ have premalignant lesions in one or two mammary glands (159). Dogs with premalignant lesions may progress to invasive cancer in one year (160), allowing for the testing of the efficacy of a vaccine in a short time. Additionally, although dogs are more outbred compared with laboratory rodents, certain breeds are at an increased risk of developing mammary tumors. Given the high homology between the canine genome sequence and its human counterpart, the dog model offers an excellent resource to explore prevention strategies for triple-negative breast cancer in females, particularly high-risk BRCA1/2 mutation carriers.

\section{Acknowledgements}

The authors would like to thank previous and current members of the Dr Sulma Mohammed lab for their help and improvement of this work.

\section{Funding}

No funding was received.

\section{Availability of data and materials}

Not applicable.

\section{Authors' contributions}

SMA wrote the first draft and SMedited the final manuscript. All authors read and approved the final manuscript.

\section{Ethics approval and consent to participate}

Not applicable.

\section{Consent for publication}

Not applicable.

\section{Competing interests}

The authors declare that they have no competing interests.

\section{References}

1. Ghoncheh M, Pournamdar Z and Salehiniya H: Incidence and mortality and epidemiology of breast cancer in the world. Asian Pac J Cancer Prev 17: 43-46, 2016.

2. DeSantis CE, Bray F, Ferlay J, Lortet-Tieulent J, Anderson BO and Jemal A: International variation in female breast cancer incidence and mortality rates. Cancer Epidemiol Biomarkers Prev 24: 1495-1506, 2015.

3. American Cancer Society: Cancer Facts \& Figures. American Cancer Society, Inc., Atlanta, GA, 2015.
4. Gazdar AF, Kurvari V, Virmani A, Gollahon L, Sakaguchi M, Westerfield M, Kodagoda D, Stasny V, Cunningham HT, Wistuba II, et al: Characterization of paired tumor and non-tumor cell lines established from patients with breast cancer. Int J Cancer 78: 766-774, 1998.

5. Holen I, Speirs V, Morrissey B and Blyth K: In vivo models in breast cancer research: Progress, challenges and future directions. Dis Model Mech 10: 359-371, 2017.

6. Levenson AS and Jordan VC: MCF-7: The first hormone-responsive breast cancer cell line. Cancer Res 57: 3071-3078, 1997.

7. Osborne CK, Hobbs K and Trent JM: Biological differences among MCF-7 human breast cancer cell lines from different laboratories. Breast Cancer Res Treat 9: 111-121, 1987.

8. Burdall SE, Hanby AM, Lansdown MR and Speirs V: Breast cancer cell lines: Friend or foe? Breast Cancer Res 5: 89-95, 2003

9. Amadori D, Bertoni L, Flamigni A, Savini S, De Giovanni C, Casanova S, De Paola F, Amadori A, Giulotto E and Zoli W: Establishment and characterization of a new cell line from primary human breast carcinoma. Breast Cancer Res Treat 28: 251-260, 1993.

10. Yong JW, Choong ML, Wang S, Wang Y, Lim SQ and Lee MA: Characterization of ductal carcinoma in situ cell lines established from breast tumor of a Singapore Chinese patient. Cancer Cell Int 14: 94, 2014.

11. Meltzer P, Leibovitz A, Dalton W, Villar H, Kute T, Davis J Nagle R and Trent J: Establishment of two new cell lines derived from human breast carcinomas with HER-2/neu amplification. Br J Cancer 63: 727-735, 1991.

12. Cailleau R, Olivé M and Cruciger QV: Long-term human breast carcinoma cell lines of metastatic origin: Preliminary characterization. In vitro 14: 911-915, 1978.

13. Engel LW and Young NA: Human breast carcinoma cells in continuous culture: A review. Cancer Res 38: 4327-4339, 1978.

14. Nayak SK, Kakati S, Harvey SR, Malone CC, Cornforth AN and Dillman RO: Characterization of cancer cell lines established from two human metastatic breast cancers. In vitro Cell Dev Biol Anim 36: 188-193, 2000.

15. Kurebayashi J, Otsuki T, Tang CK, Kurosumi M, Yamamoto S, Tanaka K, Mochizuki M, Nakamura H and Sonoo H: Isolation and characterization of a new human breast cancer cell line, KPL-4, expressing the Erb B family receptors and interleukin-6. Br J Cancer 79: 707-717, 1999.

16. Rye PD, Norum L, Olsen DR, Garman-Vik S, Kaul S and Fodstad O: Brain metastasis model in athymic nude mice using a novel MUC1-secreting human breast-cancer cell line, MA11. Int J Cancer 68: 682-687, 1996.

17. Zoli W, Roncuzzi L, Flamigni A, Gruppioni R, Sensi A, Zini N, Amadori D and Gasperi-Campani A: A new cell line from human infiltrating ductal carcinoma of the breast: Establishment and characterization. J Cancer Res Clin Oncol 122: 237-242, 1996.

18. Engel LW, Young NA, Tralka TS, Lippman ME, O'Brien SJ and Joyce MJ: Establishment and characterization of three new continuous cell lines derived from human breast carcinomas. Cancer Res 38: 3352-3364, 1978.

19. Engebraaten O and Fodstad O: Site-specific experimental metastasis patterns of two human breast cancer cell lines in nude rats. Int J Cancer 82: 219-225, 1999.

20. Lacroix M and Leclercq G: Relevance of breast cancer cell lines as models for breast tumours: An update. Breast Cancer Res Treat 83: 249-289, 2004

21. Nelson-Rees WA, Daniels DW and Flandermeyer RR: Cross-contamination of cells in culture. Science 212: 446-452, 1981.

22. Rivenbark AG, O'Connor SM and Coleman WB: Molecular and cellular heterogeneity in breast cancer: Challenges for personalized medicine. Am J Pathol 183: 1113-1124, 2013.

23. Weiswald LB, Bellet D and Dangles-Marie V: Spherical cancer models in tumor biology. Neoplasia 17: 1-15, 2015.

24. Ethier SP, Mahacek ML, Gullick WJ, Frank TS and Weber BL: Differential isolation of normal luminal mammary epithelial cells and breastcancercellsfromprimaryandmetastaticsitesusingselectivemedia. Cancer Res 53: 627-635, 1993.

25. Wistuba II, Behrens C, Milchgrub S, Syed S, Ahmadian M, Virmani AK, Kurvari V, Cunningham TH, Ashfaq R, Minna JD and Gazdar AF: Comparison of features of human breast cancer cell lines and their corresponding tumors. Clin Cancer Res 4: 2931-2938, 1998

26. Latimer JJ,Nazir T,Flowers LC,Forlenza MJ,Beaudry-Rodgers K, Kelly CM, Conte JA, Shestak K, Kanbour-Shakir A and Grant SG: Unique tissue-specific level of DNA nucleotide excision repair in primary human mammary epithelial cultures. Exp Cell Res 291: 111-121, 2003. 
27. Freshney RI: Animal cell culture: a practical approach. IRL Press (Oxford University Press), Oxford, 1992.

28. Kim IS and Baek SH: Mouse models for breast cancer metastasis Biochem Biophys Res Commun 394: 443-447, 2010.

29. Allred DC and Medina D: The relevance of mouse models to understanding the development and progression of human breast cancer. J Mammary Gland Biol Neoplasia 13: 279-288, 2008.

30. Lewis MT and Porter WW: Methods in mammary gland biology and breast cancer research: An update. J Mammary Gland Biol Neoplasia 14: 365, 2009.

31. PerezC,Parker-Thornburg J,Mikulec C, Kusewitt DF,Fischer SM, Digiovanni J, Conti CJ and Benavides F: SKHIN/Sprd, a new genetically defined inbred hairless mouse strain for UV-induced skin carcinogenesis studies. Exp Dermatol 21: 217-220, 2012.

32. Borowsky A: Special considerations in mouse models of breast cancer. Breast Dis 28: 29-38, 2007.

33. Shen Q and Brown PH: Novel agents for the prevention of breast cancer: Targeting transcription factors and signal transduction pathways. J Mammary Gland Biol Neoplasia 8: 45-73, 2003.

34. Huijbers IJ, Krimpenfort P, Berns A and Jonkers J: Rapid validation of cancer genes in chimeras derived from established genetically engineered mouse models. Bioessays 33: 701-710, 2011.

35. Ruggeri BA, Camp F and Miknyoczki S: Animal models of disease: Pre-clinical animal models of cancer and their applications and utility in drug discovery. Biochem Pharmacol 87: 150-161, 2014

36. Du Z and Li Y: RCAS-TVA in the mammary gland: An in vivo oncogene screen and a high fidelity model for breast transformation? Cell Cycle 6: 823-826, 2007.

37. Balmain A and Harris CC: Carcinogenesis in mouse and human cells: Parallels and paradoxes. Carcinogenesis 21: 371-377, 2000.

38. Barrett JC: Mechanisms of multistep carcinogenesis and carcinogen risk assessment. Environ Health Perspect 100: 9-20, 1993.

39. Steele VE, Moon RC, Lubet RA, Grubbs CJ, Reddy BS, Wargovich M, McCormick DL, Pereira MA, Crowell JA, Bagheri D, et al: Preclinical efficacy evaluation of potential chemopreventive agents in animal carcinogenesis models: Methods and results from the NCI chemoprevention drug development program. J Cell Biochem Suppl 20: 32-54, 1994.

40. Abel EL, Angel JM, Kiguchi K and DiGiovanni J: Multi-stage chemical carcinogenesis in mouse skin: Fundamentals and applications. Nat Protoc 4: 1350-1362, 2009.

41. Tsukamoto T, Mizoshita T and Tatematsu M: Animal models of stomach carcinogenesis. Toxicol Pathol 35: 636-648, 2007.

42. Takahashi M, Hori M, Mutoh M, Wakabayashi K and Nakagama H: Experimental animal models of pancreatic carcinogenesis for prevention studies and their relevance to human disease. Cancers (Basel) 3: 582-602, 2011.

43. Grivennikov SI, Greten FR and Karin M: Immunity, inflammation, and cancer. Cell 140: 883-899, 2010.

44. ShoushtariAN,Michalowska AMand Green JE: Comparing genetically engineered mouse mammary cancer models with human breast cancer by expression profiling. Breast Dis 28: 39-51, 2007.

45. Pichon MF, Broet P, Magdelenat H, Delarue JC, Spyratos F, Basuyau JP, Saez S, Rallet A, Courriere P, Millon R and Asselain B: Prognostic value of steroid receptors after long-term follow-up of 2257 operable breast cancers. Br J Cancer 73 : $1545-1551,1996$

46. Schernhammer ES, Holly JM, Hunter DJ, Pollak MN and Hankinson SE: Insulin-like growth factor-I, its binding proteins (IGFBP-1 and IGFBP-3), and growth hormone and breast cancer risk in the nurses health study II. Endocr Relat Cancer 13 583-592, 2006.

47. Kleinberg DL, Wood TL, Furth PA and Lee AV: Growth hormone and insulin-like growth factor-I in the transition from normal mammary development to preneoplastic mammary lesions. Endocr Rev 30: 51-74, 2009.

48. Selman PJ, Mol JA, Rutteman GR, van Garderen E and Rijnberk A: Progestin-induced growth hormone excess in the dog originates in the mammary gland. Endocrinology 134 287-292, 1994

49. Mehta RR, Graves JM, Hart GD, Shilkaitis A and Das Gupta TK Growth and metastasis of human breast carcinomas with Matrigel in athymic mice. Breast Cancer Res Treat 25: 65-71, 1993.

50. Gandhi A, Holland PA, Knox WF, Potten CS and Bundred NJ: Effects of a pure antiestrogen on apoptosis and proliferation within human breast ductal carcinoma in situ. Cancer Res 60: 4284-4288, 2000
51. Chan KC, Knox WF, Gee JM, Morris J, Nicholson RI, Potten CS and Bundred NJ: Effect of epidermal growth factor receptor tyrosine kinase inhibition on epithelial proliferation in normal and premalignant breast. Cancer Res 62: 122-128, 2002.

52. Shanks N, Greek R and Greek J: Are animal models predictive for humans? Philos Ethics Humanit Med 4: 2, 2009.

53. Ericsson AC, Crim MJ and Franklin CL: A brief history of animal modeling. Mo Med 110: 201-205, 2013.

54. Russo J, Gusterson BA, Rogers AE, Russo IH, Wellings SR and van Zwieten MJ: Comparative study of human and rat mammary tumorigenesis. Lab Invest 62: 244-278, 1990.

55. Russo J and Russo IH: Atlas and histologic classification of tumors of the rat mammary gland. J Mammary Gland Biol Neoplasia 5: 187-200, 2000

56. Szpirer C: Cancer research in rat models. Methods Mol Biol 597: 445-458, 2010

57. Russo IH and Russo J: Developmental stage of the rat mammary gland as determinant of its susceptibility to 7,12-dimethylbenz[a] anthracene. J Natl Cancer Inst 61: 1439-1449, 1978.

58. Thompson HJ, Adlakha H and Singh M: Effect of carcinogen dose and age at administration on induction of mammary carcinogenesis by 1-methyl-1-nitrosourea. Carcinogenesis 13: $1535-1539,1992$.

59. Thompson HJ and Meeker LD: Induction of mammary gland carcinomas by the subcutaneous injection of 1-methyl-1-nitrosourea. Cancer Res 43: 1628-1629, 1983.

60. Russo J, Balogh GA, Heulings R, Mailo DA, Moral R, Russo PA, Sheriff F, Vanegas J and Russo IH: Molecular basis of pregnancy-induced breast cancer protection. Eur J Cancer Prev 15: 306-342, 2006.

61. Nandi S, Guzman RC and Yang J: Hormones and mammary carcinogenesis in mice, rats, and humans: A unifying hypothesis. Proc Natl Acad Sci USA 92: 3650-3657, 1995.

62. Holliday R: Neoplastic transformation: The contrasting stability of human and mouse cells. Cancer Surv 28: 103-115, 1996.

63. Holt MP, Shevach EM and Punkosdy GA: Endogenous mouse mammary tumor viruses (mtv): New roles for an old virus in cancer, infection and immunity. Front Oncol 3: 287, 2013.

64. Wong M, Pagano JS, Schiller JT, Tevethia SS, Raab-Traub N and Gruber J: New associations of human papillomavirus, Simian virus 40, and Epstein-Barr virus with human cancer. J Natl Cancer Inst 94: 1832-1836, 2002.

65. Newbold RF: Genetic control of telomerase and replicative senescence in human and rodent cells. Ciba Found Symp 211: 177-197, 1997.

66. Greenberg RA, Allsopp RC, Chin L, Morin GB and DePinho RA: Expression of mouse telomerase reverse transcriptase during development, differentiation and proliferation. Oncogene 16: 1723-1730, 1998

67. Cabuy E, Newton C, Roberts T, Newbold R and Slijepcevic P Identification of subpopulations of cells with differing telomere lengths in mouse and human cell lines by flow FISH. Cytometry A 62: 150-161, 2004.

68. Cardiff RD, Anver MR, Gusterson BA, Hennighausen L, Jensen RA, Merino MJ, Rehm S, Russo J, Tavassoli FA, Wakefield LM, et al: The mammary pathology of genetically engineered mice: The consensus report and recommendations from the Annapolis meeting. Oncogene 19: 968-988, 2000.

69. Cardiff RD: Validity of mouse mammary tumour models for human breast cancer: Comparative pathology. Microsc Res Tech 52: 224-230, 2001

70. Savage VM, Allen AP, Brown JH, Gillooly JF, Herman AB, Woodruff WH and West GB: Scaling of number, size, and metabolic rate of cells with body size in mammals. Proc Natl Acad Sci USA 104: 4718-4723, 2007.

71. Helczynska K, Kronblad A, Jögi A, Nilsson E, Beckman S, Landberg G and Påhlman S: Hypoxia promotes a dedifferentiated phenotype in ductal breast carcinoma in situ. Cancer Res 63: $1441-1444,2003$

72. Walrath JC, Hawes JJ, Van Dyke T and Reilly KM: Genetically engineered mouse models in cancer research. Adv Cancer Res 106: 113-164, 2010

73. Gomez-Cuadrado L, Tracey N, Ma R, Qian B and Brunton VG: Mouse models of metastasis: Progress and prospects. Dis Model Mech 10: 1061-1074, 2017.

74. Frese KK and Tuveson DA: Maximizing mouse cancer models Nat Rev Cancer 7: 645-658, 2007.

75. Rahman M and Mohammed S: Breast cancer metastasis and the lymphatic system. Oncol Lett 10: 1233-1239, 2015. 
76. Kucherlapati R: Genetically modified mouse models for biomarker discovery and preclinical drug testing. Clin Cancer Res 18: 625-630, 2012.

77. Olive KP and Tuveson DA: The use of targeted mouse models for preclinical testing of novel cancer therapeutics. Clin Cancer Res 12: 5277-5287, 2006

78. Huang G, Ashton C, Kumbhani DS and Ying QL: Genetic manipulations in the rat: Progress and prospects. Curr Opin Nephrol Hypertens 20: 391-399, 2011.

79. Cheung A, Young L, Chen P, Chao C, Ndoye A, Barry P, Muller W and Cardiff R: Microcirculation and metastasis in a new mouse mammary tumor model system. Int J Oncol 11: 69-77, 1997.

80. Wiese DA, Thaiwong T, Yuzbasiyan-Gurkan V and Kiupel M: Feline mammary basal-like adenocarcinomas: A potentia model for human triple-negative breast cancer (TNBC) with basal-like subtype. BMC Cancer 13: 403, 2013.

81. De Maria R, Olivero M, Iussich S, Nakaichi M, Murata T, Biolatti B and Di Renzo MF: Spontaneous feline mammary carcinoma is a model of HER2 overexpressing poor prognosis human breast cancer. Cancer Res 65: 907-912, 2005.

82. Burrai GP, Mohammed SI, Miller MA, Marras V, Pirino S, Addis MF, Uzzau S and Antuofermo E: Spontaneous feline mammary intraepithelial lesions as a model for human estrogen receptor- and progesterone receptor-negative breast lesions BMC Cancer 10: 156, 2010

83. Weijer K, Head KW, Misdorp W and Hampe JF: Feline malignant mammary tumors. I. Morphology and biology: Some comparisons with human and canine mammary carcinomas. J Natl Cancer Inst 49: 1697-1704, 1972.

84.Li W, Xiao C, Vonderhaar BK and Deng CX: A role of estrogen/ERalpha signaling in BRCA1-associated tissue-specific tumor formation. Oncogene 26: 7204-7212, 2007

85. Lin SC, Lee KF, Nikitin AY, Hilsenbeck SG, Cardiff RD, Li A, Kang KW, Frank SA, Lee WH and Lee EY: Somatic mutation of p53 leads to estrogen receptor alpha-positive and -negative mouse mammary tumors with high frequency of metastasis Cancer Res 64: 3525-3532, 2004.

86. Jang JW, Boxer RB and Chodosh LA: Isoform-specific ras activation and oncogene dependence during MYC- and Wnt-induced mammary tumorigenesis. Mol Cell Biol 26: 8109-8121, 2006.

87. Owen LN: A comparative study of canine and human breast cancer. Invest Cell Pathol 2: 257-275, 1979.

88. Queiroga FL, Raposo T, Carvalho MI, Prada J and Pires I: Canine mammary tumours as a model to study human breast cancer: Most recent findings. In vivo 25: 455-465, 2011.

89. Glass AG, Lacey JV Jr, Carreon JD and Hoover RN: Breast cancer incidence, 1980-2006: combined roles of menopausal hormone therapy, screening mammography, and estrogen receptor status. J Natl Cancer Inst 99: 1152-1161, 2007.

90. Pollan M, Pastor-Barriuso R, Ardanaz E, Argüelles M, Martos C, Galcerán J, Sánchez-Pérez MJ, Chirlaque MD, Larrañaga N, Martínez-Cobo R, et al: Recent changes in breast cancer incidence in Spain, 1980-2004. J Natl Cancer Inst 101: 1584-1591, 2009.

91. Dobson JM, Samuel S, Milstein H, Rogers K and Wood JL: Canine neoplasia in the UK: Estimates of incidence rates from a population of insured dogs. J Small Anim Pract 43: 240-246, 2002 .

92. Misdorp W; Armed Forces Institute of Pathology (U.S.); American Registry of Pathology.; WHO Collaborating Center for Worldwide Reference on Comparative Oncology: Histological classification of mammary tumors of the dog and the cat. Washington: Armed Forces Institute of Pathology in cooperation with the American Registry of Pathology and the World Health Organization Collaborating Center for Worldwide Reference on Comparative Oncology. Comp Oncol 7: 59, 1999.

93. Antuofermo E, Miller MA, Pirino S, Xie J, Badve S and Mohammed SI: Spontaneous mammary intraepithelial lesions in dogs-a model of breast cancer. Cancer Epidemiol Biomarkers Prev 16: 2247-2256, 2007.

94. Schneider R: Comparison of age, sex, and incidence rates in human and canine breast cancer. Cancer 26: 419-426, 1970.

95. Rutteman GR, Misdorp W, Blankenstein MA and van den Brom WE: Oestrogen (ER) and progestin receptors $(\mathrm{PR})$ in mammary tissue of the female dog: different receptor profile in non-malignant and malignant states. $\mathrm{Br} \mathrm{J}$ Cancer 58 594-599, 1988.

96. Fisher ER, Sass R and Fisher B: Pathologic findings from the national surgical adjuvant breast project. Correlations with concordant and discordant estrogen and progesterone receptors. Cancer 59: 1554-1559, 1987
97. Lamote I, Meyer E, Massart-Leen AM and Burvenich C: Sex steroids and growth factors in the regulation of mammary gland proliferation, differentiation, and involution. Steroids 69 : 145-159, 2004

98. Elston CW: Classification and grading of invasive breast carcinoma. Verh Dtsch Ges Pathol 89: 35-44, 2005.

99. Martín de las Mulas J, Ordás J, Millán MY, Chacón F, De Lara M, Espinosa de los Monteros A, Reymundo C and Jover A: Immunohistochemical expression of estrogen receptor beta in normal and tumoral canine mammary glands. Vet Pathol 41: 269-272, 2004

100. Gruvberger-Saal SK, Bendahl PO, Saal LH, Laakso M, Hegardt C, Edén P, Peterson C, Malmström P, Isola J, Borg A and Fernö M: Estrogen receptor beta expression is associated with tamoxifen response in ERalpha-negative breast carcinoma. Clin Cancer Res 13: 1987-1994, 2007.

101. Saji S, Hirose M and Toi M: Clinical significance of estrogen receptor beta in breast cancer. Cancer Chemother Pharmacol 56 (Suppl 1): S21-S26, 2005.

102. Joensuu K, Leidenius M, Kero M, Andersson LC, Horwitz KB and Heikkilä P: ER, PR, HER2, Ki-67 and CK5 in early and late relapsing breast cancer-reduced CK5 expression in metastases. Breast Cancer (Auckl) 7: 23-34, 2013.

103. Gelbfish GA, Davidson AL, Kopel S, Schreibman B, Gelbfish JS, Degenshein GA, Herz BL and Cunningham JN: Relationship of estrogen and progesterone receptors to prognosis in breast cancer. Ann Surg 207: 75-79, 1988.

104. Mouttet D, Laé M, Caly M, Gentien D, Carpentier S, Peyro-Saint-Paul H, Vincent-Salomon A, Rouzier R, Sigal-Zafrani B, Sastre-Garau X and Reyal F: Estrogen-receptor, progesterone-receptor and HER2 status determination in invasive breast cancer. Concordance between immuno-histochemistry and MapQuant ${ }^{\mathrm{TM}}$ microarray based assay. PLoS One 11: e0146474, 2016.

105. Krajcik RA, Borofsky ND, Massardo S and Orentreich N: Insulin-like growth factor I (IGF-I), IGF-binding proteins, and breast cancer. Cancer Epidemiol Biomarkers Prev 11: 1566-1573, 2002.

106. van Garderen E, de Wit M, Voorhout WF, Rutteman GR, Mol JA, Nederbragt $\mathrm{H}$ and Misdorp W: Expression of growth hormone in canine mammary tissue and mammary tumors. Evidence for a potential autocrine/paracrine stimulatory loop. Am J Pathol 150: 1037-1047, 1997.

107. van Garderen E, van der Poel HJ, Swennenhuis JF, Wissink EH, Rutteman GR, Hellmén E, Mol JA and Schalken JA: Expression and molecular characterization of the growth hormone receptor in canine mammary tissue and mammary tumors. Endocrinology 140: 5907-5914, 1999.

108. Divisova J, Kuiatse I, Lazard Z, Weiss H, Vreeland F, Hadsell DL, Schiff R, Osborne CK and Lee AV: The growth hormone receptor antagonist pegvisomant blocks both mammary gland development and MCF-7 breast cancer xenograft growth. Breast Cancer Res Treat 98: 315-327, 2006.

109. Queiroga FL, Pérez-Alenza MD, Silvan G, Peña L, Lopes CS and Illera JC: Crosstalk between GH/IGF-I axis and steroid hormones (progesterone, 17beta-estradiol) in canine mammary tumours. J Steroid Biochem Mol Biol 110: 76-82, 2008.

110. Queiroga FL, Pérez-Alenza D, Silvan G, Peña L, Lopes CS and Illera JC: Serum and intratumoural GH and IGF-I concentrations: Prognostic factors in the outcome of canine mammary cancer. Res Vet Sci 89: 396-403, 2010.

111. Yin D, Vreeland F, Schaaf LJ, Millham R, Duncan BA and Sharma A: Clinical pharmacodynamic effects of the growth hormone receptor antagonist pegvisomant: Implications for cancer therapy. Clin Cancer Res 13: 1000-1009, 2007.

112. Hobbs JR and Salih H: Prolactin dependence in human breast cancer. Proc R Soc Med 66: 866, 1973.

113. Ormandy CJ, Hall RE, Manning DL, Robertson JF, Blamey RW, Kelly PA, Nicholson RI and Sutherland RL: Coexpression and cross-regulation of the prolactin receptor and sex steroid hormone receptors in breast cancer. J Clin Endocrinol Metab 82: 3692-3699, 1997.

114. Queiroga FL, Pérez-Alenza MD, Silvan G, Peña L, Lopes C and Illera JC: Role of steroid hormones and prolactin in canine mammary cancer. J Steroid Biochem Mol Biol 94: 181-187, 2005.

115. Visan S, Balacescu O, Berindan-Neagoe I and Catoi C: In vitro comparative models for canine and human breast cancers. Clujul Med 89: 38-49, 2016.

116. Uva P, Aurisicchio L, Watters J, Loboda A, Kulkarni A, Castle J, Palombo F, Viti V, Mesiti G, Zappulli V, et al: Comparative expression pathway analysis of human and canine mammary tumors. BMC Genomics 10: 135, 2009. 
117. Egenvall A, Bonnett BN, Ohagen P, Olson P, Hedhammar A and von Euler H: Incidence of and survival after mammary tumors in a population of over 80,000 insured female dogs in Sweden from 1995 to 2002. Prev Vet Med 69: 109-127, 2005.

118. Rivera P, Melin M, Biagi T, Fall T, Häggström J, Lindblad-Toh K and von Euler H: Mammary tumor development in dogs is associated with BRCA1 and BRCA2. Cancer Res 69: 8770-8774, 2009.

119. Ochiai K, Morimatsu M, Tomizawa N and Syuto B: Cloning and sequencing full length of canine Brca2 and Rad51 cDNA. J Vet Med Sci 63: 1103-1108, 2001.

120. Nieto A, Pérez-Alenza MD, Del Castillo N, Tabanera E, Castaño M and Peña L: BRCA1 expression in canine mammary dysplasias and tumours: Relationship with prognostic variables. J Comp Pathol 128: 260-268, 2003.

121. Klopfleisch R and Gruber AD: Increased expression of BRCA2 and RAD51 in lymph node metastases of canine mammary adenocarcinomas. Vet Pathol 46: 416-422, 2009.

122. Rajan JV, Marquis ST, Gardner HP and Chodosh LA: Developmental expression of Brca2 colocalizes with Brca1 and is associated with proliferation and differentiation in multiple tissues. Dev Biol 184: 385-401, 1997.

123. Rakha EA, El-Sayed ME, Green AR, Lee AH, Robertson JF and Ellis IO: Prognostic markers in triple-negative breast cancer. Cancer 109: 25-32, 2007.

124. Gama A, GärtnerF, Alves A and SchmittF:Immunohistochemica expression of Epidermal Growth Factor Receptor (EGFR) in canine mammary tissues. Res Vet Sci 87: 432-437, 2009.

125. Queiroga FL,Perez-AlenzaD, Silvan G,Peña Land Illera JC: Positive correlation of steroid hormones and EGF in canine mammary cancer. J Steroid Biochem Mol Biol 115: 9-13, 2009.

126. Ross JS, Fletcher JA, Linette GP, Stec J, Clark E, Ayers M, Symmans WF, Pusztai L and Bloom KJ: The Her-2/neu gene and protein in breast cancer 2003: Biomarker and target of therapy. Oncologist 8: 307-325, 2003.

127. Rungsipipat A, Tateyama S, Yamaguchi R, Uchida K, Miyoshi N and Hayashi T: Immunohistochemical analysis of c-yes and c-erbB-2 oncogene products and p53 tumor suppressor protein in canine mammary tumors. J Vet Med Sci 61: 27-32, 1999.

128. Kerns BJ, Pence JC, Huper G, Kinney RB and Iglehart JD: c-erbB-2 expression in breast cancer detected by immunoblotting and immunohistochemistry. J Histochem Cytochem 38 1823-1830, 1990.

129. Paredes J, Lopes N, Milanezi F and Schmitt FC: P-cadherin and cytokeratin 5: Useful adjunct markers to distinguish basal-like ductal carcinomas in situ. Virchows Arch 450: 73-80, 2007.

130. Abd El-Rehim DM, Pinder SE, Paish CE, Bell J, Blamey RW, Robertson JF, Nicholson RI and Ellis IO: Expression of luminal and basal cytokeratins in human breast carcinoma. J Pathol 203 661-671, 2004.

131. Gama A, Alves A and Schmitt F: Identification of molecular phenotypes in canine mammary carcinomas with clinical implications: Application of the human classification. Virchows Arch 453: 123-132, 2008.

132. Gerdes J, Lemke H, Baisch H, Wacker HH, Schwab U and Stein $\mathrm{H}$ : Cell cycle analysis of a cell proliferation-associated human nuclear antigen defined by the monoclonal antibody Ki-67. J Immunol 133: 1710-1715, 1984.

133. Peña LL, Nieto AI, Pérez-Alenza D, Cuesta $P$ and Castaño $M$ : Immunohistochemical detection of $\mathrm{Ki}-67$ and PCNA in canine mammary tumors: Relationship to clinical and pathologic variables. J Vet Diagn Invest 10: 237-246, 1998.

134. Railo M, Nordling S, von Boguslawsky K, Leivonen M, Kyllönen L and von Smitten K: Prognostic value of Ki-67 immunolabelling in primary operable breast cancer. Br J Cancer 68: 579-583, 1993.

135. Thomas M, Noguchi M, Kitagawa H, Kinoshita K and Miyazaki I Poor prognostic value of proliferating cell nuclear antigen labelling index in breast carcinoma. J Clin Pathol 46: 525-528, 1993

136. Funakoshi Y, Nakayama H, Uetsuka K, Nishimura R, Sasaki N and Doi K: Cellular proliferative and telomerase activity in canine mammary gland tumors. Vet Pathol 37: 177-183, 2000.

137. Kumaraguruparan R, Prathiba D and Nagini S: Of humans and canines: Immunohistochemical analysis of PCNA, Bcl-2, p53, cytokeratin and ER in mammary tumours. Res Vet Sci 81: 218-224, 2006.

138. Velculescu VE and El-Deiry WS: Biological and clinical importance of the p53 tumor suppressor gene. Clin Chem 42: 858-868, 1996

139. Beenken SW, Grizzle WE, Crowe DR, Conner MG, Weiss HL, Sellers MT, Krontiras H, Urist MM and Bland KI: Molecular biomarkers for breast cancer prognosis: Coexpression of c-erbB-2 and p53. Ann Surg 233: 630-638, 2001.
140. Lee $\mathrm{CH}$ and Kweon OK: Mutations of $\mathrm{p} 53$ tumor suppressor gene in spontaneous canine mammary tumors. J Vet Sci 3: 321-325, 2002.

141. Chu LL, Rutteman GR, Kong JM, Ghahremani M, Schmeing M, Misdorp W, van Garderen E and Pelletier J: Genomic organization of the canine p53 gene and its mutational status in canine mammary neoplasia. Breast Cancer Res Treat 50: 11-25, 1998.

142. Veldhoen N, Watterson J, Brash M and Milner J: Identification of tumour-associated and germ line p53 mutations in canine mammary cancer. Br J Cancer 81: 409-415, 1999.

143. Muto T, Wakui S, Takahashi H, Maekawa S, Masaoka T, Ushigome S and Furusato M: p53 gene mutations occurring in spontaneous benign and malignant mammary tumors of the dog. Vet Pathol 37: 248-253, 2000.

144. Moll UM and Slade N: p63 and p73: Roles in development and tumor formation. Mol Cancer Res 2: 371-386, 2004.

145. McKeon FD: p63 and p73 in tumor suppression and promotion. Cancer Res Treat 36: 6-12, 2004.

146. Matos I, Dufloth R, Alvarenga M, Zeferino LC and Schmitt F: p63, cytokeratin 5, and P-cadherin: Three molecular markers to distinguish basal phenotype in breast carcinomas. Virchows Arch 447: 688-694, 2005.

147. Stefanou D, Batistatou A, Nonni A, Arkoumani E and Agnantis NJ: p63 expression in benign and malignant breast lesions. Histol Histopathol 19: 465-471, 2004.

148. C and Desantis RS and Jemal A: Breast cancer facts \& figures 2015-2016. Am Cancer Soc: 44, 2015.

149. Gama A, Alves A, Gartner F and Schmitt F: p63: A novel myoepithelial cell marker in canine mammary tissues. Vet Pathol 40: 412-420, 2003.

150. Elmore JG, Armstrong K, Lehman CD and Fletcher SW: Screening for breast cancer. JAMA 293: 1245-1256, 2005.

151. Morgan MP, Cooke MM and McCarthy GM: Microcalcifications associated with breast cancer: An epiphenomenon or biologically significant feature of selected tumors? J Mammary Gland Biol Neoplasia 10: 181-187, 2005.

152. Muttarak M, Kongmebhol P and Sukhamwang N: Breast calcifications: Which are malignant? Singapore Med J 50: 907-914, 2009

153. Burnside ES, Sickles EA, Bassett LW, Rubin DL, Lee CH, Ikeda DM, Mendelson EB, Wilcox PA, Butler PF and D'Orsi CJ: The ACR BI-RADS experience: Learning from history. J Am Coll Radiol 6: 851-860, 2009.

154. Ernster VL and Barclay J: Increases in ductal carcinoma in situ (DCIS) of the breast in relation to mammography: A dilemma. J Natl Cancer Inst Monogr: 151-156, 1997.

155. Mohammed SI, Meloni GB, Pinna Parpaglia ML, Marras V, Burrai GP, Meloni F, Pirino S and Antuofermo E: Mammography and ultrasound imaging of preinvasive and invasive canine spontaneous mammary cancer and their similarities to human breast cancer. Cancer Prev Res (Phila) 4: 1790-1798, 2011.

156. Cekanova M and Rathore K: Animal models and therapeutic molecular targets of cancer: Utility and limitations. Drug Des Devel Ther 8: 1911-1921, 2014

157. Decker WK, da Silva RF, Sanabria MH, Angelo LS, Guimarães F, Burt BM, Kheradmand F and Paust S: Cancer immunotherapy: Historical perspective of a clinical revolution and emerging preclinical animal models. Front Immunol 8: 829, 2017

158. Estrela-Lima A, Araújo MS, Costa-Neto JM, TeixeiraCarvalho A, Barrouin-Melo SM, Cardoso SV, Martins-Filho OA, Serakides R and Cassali GD: Immunophenotypic features of tumor infiltrating lymphocytes from mammary carcinomas in female dogs associated with prognostic factors and survival rates. BMC Cancer 10: 256, 2010.

159. Akiyama F and Horii R: Therapeutic strategies for breast cancer based on histological type. Breast Cancer 16: 168-172, 2009.

160. Sorenmo KU, Kristiansen VM, Cofone MA, Shofer FS, Breen AM, Langeland M, Mongil CM, Grondahl AM, Teige J and Goldschmidt MH: Canine mammary gland tumours; a histological continuum from benign to malignant; clinical and histopathological evidence. Vet Comp Oncol 7: 162-172, 2009.

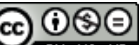

This work is licensed under a Creative Commons Attribution-NonCommercial-NoDerivatives 4.0 International (CC BY-NC-ND 4.0) License. 